\title{
ПРОБЛЕМА ЗЛОУПОТРЕБЛЕНИЯ ПРОЦЕССУАЛЬНЫМИ ПРАВАМИ В АРБИТРАЖНОМ СУДОПРОИЗВОДСТВЕ
}

\author{
(c) 2021 Лошкарёв А. В. \\ кандидат юридических наук \\ Самарский государственный экономический университет, Россия, Самара \\ E-mail:2482337@mail.ru \\ (c) 2021 Чалоян А.И. \\ магистрант \\ Самарский государственный экономический университет, Россия, Самара \\ E-mail: milashka25e@mail.ru
}

В данной статье исследуется проблема разграничения добросовестного пользования субъективными правами и злоупотребления процессуальными правами. И поскольку актуальность данного вопроса со временем только возрастает, то целью данного исследования можно назвать анализ существующих проблем, связанных с ответственностью за злоупотребление процессуальными правами в арбитражном процессе, а также поиск возможных путей их решения.

Ключевые слова: арбитражное судопроизводство, злоупотребление процессуальными правами, добросовестное использование субъективных прав.

В Российской Федерации защита оспариваемых и нарушенных прав и законных интересов лиц, которые осуществляют предпринимательскую и иную экономическую деятельность, является одной из задач арбитражного судопроизводства. Такая деятельность характеризуется высоким риском со стороны ее участников, поэтому задача законодателя предусмотреть особые правовые средства, служащие для ограничения нарушений и злоупотреблений со стороны участников гражданского оборота.

Однако, несмотря на повышенное внимание законодательной власти к повышению уровня судебной защиты в Российской Федерации за последние несколько лет, в процессе правоприменительной деятельности обнаруживается несостоятельность процессуального законодательства в части исключения злоупотребления процессуальными правами участниками предпринимательской деятельности.

Согласно ратифицированной Европейской Конвенции о защите прав человека и основных свобод, государства-участники этой Конвенции обязуются гарантировать доступность правосудия и эффективность предоставленных средств правовой защиты [1].

В соответствии со ст. 2 Конституции Российской Федерации от 12.12.1993 (далее - Конституции РФ) [2] человек, его права и свободы являются высшей ценностью. Защита прав и свобод человека и гражданина является одной из конституционных обязанностей государства.

Важнейшим элементом правового статуса личности в Российской Федерации является гарантируемое право граждан на судебную защиту (ч. 1 ст. 45 Конституции РФ).

Конституцией признается право каждого защищать свои права и свободы всеми способами, не запрещенными законом. Это свидетельствует о том, что Российская Федерация, как правовое государство, исходит из расширительного толкования прав и основных свобод, то есть исходит из принципа «разрешено все, что не запрещено». Оно поощряет активную жизненную позицию своих граждан и каждого, кто находится на территории РФ на законных основаниях, по самостоятельной защите своих прав и свобод с применением всех предусмотренных законодательством возможностей.

Статья 46 Конституции РФ предусматривает гарантию права на судебную защиту его прав и свобод. Данное конституционное положение находит свое логическое продолжение и подтверждение в нормах законодательства Российской Федерации, в т.ч. в нормах арбитражнопроцессуального права.

Раскрытие понятия злоупотребления процессуальными правами наиболее результативно проводить через призму его роли и социального назначения, цели внедрения в процессуальное 
законодательство и через обозначение основных признаков и видов.

Несмотря на провозглашенные Конституцией и иными законодательными актами Российской Федерации гарантии защиты прав и законных интересов субъектов права, современные реалии деятельности юрисдикционных органов показывают, что они не реализуются фактически.

Такими причинами могут выступать недобросовестное поведение одной из сторон спора, которое заключается в препятствовании принятия судом решения путем преднамеренном затягивании процесса, фальсификации бухгалтерских и иных учетных документов и пр. Таким образом, сущность института обеспечительных мер обусловлена необходимостью таких правовых инструментов, которые способны ограничить приведенные выше злоупотребления.

Исходя из вышеизложенного, целью внедрения института борьбы со злоупотреблением процессуальными правами в российское законодательство является установление гарантии на справедливое судебное решение, то есть достижение целей отправления правосудия.

Институт борьбы со злоупотреблением процессуальными правами применяется не только в арбитражно-процессуальном праве, но и в других процессуальных отраслях, то есть является межотраслевым. В научной литературе существуют несколько подходов к пониманию понятия злоупотребления процессуальными правами.

Исходя из первого подхода, под злоупотреблением процессуальными правами следует понимать особую форму арбитражного процессуального нарушение, то есть умышленное недобросовестное поведение субъектов арбитражного судопроизводство [3].

Согласно второму подходу злоупотребление процессуальными правами можно представить, как реализацию участником арбитражного процесса своих субъективных прав в установленных законом рамках, но направленных на достижение целей, которые не соответствуют целям и задачам арбитражного судопроизводство [4].

Исходя из характеристики процессуальных норм, на основе которых субъективные права и обязанности участников арбитражного процесса содержат морально-нравственные принципы, можно выделить в качестве одной из отличительных черт злоупотребления правом отсут- ствие внешних признаков правонарушения, то есть законодательного запрета и несоответствующего социального поведения.

Представляется, что злоупотребление правами участниками арбитражного судопроизводства это не что иное, как правомерное, но в тоже время не соответствующее социальным требованием поведение субъекта [5].

Считаем, что именно основные принципы морили, являются регулятором, которые определяют структуру экономических правоотношений.

С этой точки зрения, совокупность моральных принципов гарантируют разумное использование права участниками правоотношения. Для добровольной реализации правовых норм участниками экономических правоотношений, необходимо воспринимать моральные начала права, как основу для добросовестной реализации субъективных прав [6].

Многие теоретики придерживаются позиции, что необходимо включить моральноэтнические начала в правовые нормы, что будет способствовать установлению пределов поведения участниками предпринимательской деятельности правовыми средствами.

Как уже отмечалось, особенностью злоупотребления процессуальными правами является то, что нет внешне выраженных признаков правонарушения. Именно этот фактор не дает возможность арбитражным судам правильно решить ряд юридических вопросов и осуществлять справедливое правосудие.

Представляется сложным провести грань между реализацией участниками арбитражного судопроизводства своих субъективных прав и недопустимым поведением, что не дает возможность в полной мере восстановить свои нарушенные права [7].

А.В.Юдин акцентировал свое внимание на том, что возникают и ситуации, когда абсолютно все правовые средства используются субъектами экономической деятельности недобросовестно в целях, которые противоречат морально-нравственным принципам общества. Такая ситуация представляет собой опасность порождения правового нигилизма [8].

Согласно части 2 ст.41 Арбитражнопроцессуального Кодекса Российской Федерации (далее - АПК РФ) [9] лица участвующие в деле должны при осуществлении своих процессуальных прав придерживаться принципа 
добросовестности, но на практике в связи с тем, что в норме нет конкретного содержание этой обязанности, данную норму не соблюдают.

Определенная попытка борьбы со злоупотреблением процессуальными правами была предпринята законодателем путем формирования санкции в статье 111 АПК РФ, которая предусматривает судебные расходы за действие или бездействие участников предпринимательской деятельности, которые обладают признаками злоупотребления.

Основные тенденции правового регулирования злоупотребления процессуальными правами сводятся к следующему.

Для начала нужно отметить, что запрет на злоупотребления правами содержатся, как в нормах международного права, так и национального. Конвенция о защите прав человека и основных свобод вводит в принцип осуществления правосудия добросовестное поведение участников предпринимательской деятельности.

Далее и национальное законодательство закрепляет положение о добросовестном поведении субъектов. Казалось бы, достаточно простые нормы для реализации, однако на практике возникает масса проблем с определением понятии злоупотребление и добросовестное поведение. Проблемы эти заключаются именно в соотношении этих понятии.

Большинство современных цивилистов под злоупотреблением понимают именно недобросовестное осуществление субъектом своих прав. А добросовестное поведение - это поведение субъекта в рамках законных предписаний [10].

Представляет проблему по рассматриваемому вопросу и отсутствие на законодательном уровне понятий и критериев, что создает правовую неопределенность.

На основе судебной практики формулировались следующие определение. Недобросовестное поведение - это такое поведение, где явно преобладают признаки отклонения от добросовестного поведения [11].

Однако здесь нельзя не отметить тот факт, что в данном случае характеризуется добросовестное поведение с материальной точки зрения, а не с процессуальной. Поэтому нужно разграничивать понятия добросовестности в материальном праве и в процессуальном. Отметим, что их объединяет общая правовая сущность в результате чего, данные понятия становятся родственными.
Отличительным характером данных понятии являются правовые последствия после их совершения.

В независимости от сферы их проявление злоупотребление правом является негативным фактором для осуществления любой деятельности. В арбитражном процессе злоупотребления процессуальными правами препятствует осуществлению основных принципов правосудия.

Также законодателем не закреплено определение понятия злоупотребления, что негативно влияет на выявление признаков и форм, процессуальных злоупотреблений.

Наиболее распространенное в юридической литературе определение злоупотребления процессуальными правами представляет злоупотребление, как особую форму правонарушения [12].

Арбитражное процессуальное законодательство не закрепляет виды и формы злоупотребления процессуальными правами, происходит это на основе судебной практики в каждом конкретном деле.

В.В.Ярков считает, что при множестве способов злоупотребления процессуальными правами, возникает необходимость для строгого осуществления принципов правосудия [13].

Выявление и недопущение процессуальных наращений, как в форме злоупотребления процессуальными правами, так и в форме неисполнения процессуальных обязанностей - это деятельность суда. В связи с этим сложно согласиться с мнением А.А.Андреева, [14] согласно которому суд является субъектом злоупотребления процессуальных прав, так как это представляется невозможным.

Постановление Пленума Верховного суда Российской Федерации от 29 марта 2016 г. № 11 «О некоторых вопросах, возникающих при рассмотрении дел о присуждении компенсации за нарушение права на судопроизводство в разумный срок или права на исполнение судебного акта в разумный срок» указывает, что при оценке действий суда, необходимо разрешить вопросы связанные с своевременностью принятия судьей всех необходимых процессуальных мер принуждения в отношении участников арбитражного процесса, которые направлены на недопущение недобросовестности и процессуальной волокиты по делу.

Однако, если суд является субъектом злоупотребления, то в данном случае представляет- 
ся целесообразным, чтобы контроль за недопущением данных злоупотреблении осуществлял специальный орган, который будет вне рамок процесса.

Формы злоупотребления процессуальными правами в арбитражном процессе многообразны, но выработка их квалификации и их анализ позволит эффективному противодействию злоупотребления процессуальными правами без вмешательства других правовых институтов и внесудебных органов.

Борьбу со злоупотреблением процессуальными правами, считаем, что необходимо осуществлять путем упрощения формы судопроизводства и закрепления в процессуальном законодательстве перечня мер ответственности за недобросовестную реализацию участниками арбитражного процесса субъективных прав.

Считаем, что совершенствование упрощенной формы судопроизводства в арбитражных судах позволит исключить многие формы процессуальных злоупотреблении, которые связанные с представлением и раскрытием доказательств, так как для данного действия суд устанавливает определенные сроки, и пропуск этого срока имеет негативные последствия в виде отказа рассматривать их в качестве доказательств [15].

Так как на законодательном уровне не закреплены виды злоупотребления процессуальными правами, суд в каждом конкретном деле рассматривает действия субъекта злоупотреблением, но чем конкретнее будут сформулированы виды злоупотребления процессуальными правами, тем эффективнее будет деятельность судьей по противодействию им [16].

Поэтапное совершенствование процессуального законодательства в части регламентации таких категорий как добросовестность и злоупотребление в арбитражном судопроизводстве, положительно повлияет на справедливое судопроизводство. И сложившейся судебная практика должна послужить основой законодательных инициатив.

\section{Библиографический список}

1. «Конвенция о защите прав человека и основных свобод» (Заключена в г. Риме 04.11.1950) (с изм. от 13.05.2004) (вместе с «Протоколом [№ 1]» (Подписан в г. Париже 20.03.1952), «Протоколом № 4 об обеспечении некоторых прав и свобод помимо тех, которые уже включены в Конвенцию и первый Протокол к ней» (Подписан в г. Страсбурге 16.09.1963), «Протоколом № 7» (Подписан в г. Страсбурге22.11.1984)) // Консультант Плюс. [Электронный ресурс]. URL: http://www.consultant.ru/document/Cons_doc_LAW_29160/ (дата обращения: 19.04.2020).

2. «Конституция Российской Федерации» (принята всенародным голосованием 12.12.1993) (с учетом поправок, внесенных Законами РФ о поправках к Конституции РФ от 30.12.2008 № 6-ФКЗ, от 30.12.2008 № 7-ФКЗ, от 05.02.2014 № 2-ФК3, от 21.07.2014 № 11-ФК3) // КонсультантПлюс. [Электронный ресурс] URL: http:// www.consultant.ru/document/Cons_doc_LAW_28399/ (дата обращения: 19.04.2020).

3. Зайков Д. Е. Понятие и содержание злоупотребления процессуальными правами в арбитражном и гражданском процессах / Д. Е. Зайков // Вестник гражданского процесса. - 2016. - № 6. - С. 187-201.

4. Аксенова О.В. Субъективные процессуальные права и их осуществление в арбитражном процессе/ О.В.Аксенова// Российская юстиция. - 2017.- № 9.- С. 24-30.

5. Абросимова, О.К. Взаимодействие права и морали в современном российском обществе/О.К. Абросимова// Арбитражный и гражданский процесс. - 2018. - № 12.- С. 29-32.

6. Арбитражный процесс [Электронный ресурс]: учебник /под ред. С.В.Никитина. Режим доступа: http:// www.consultant.ru/cons/cgi/online.cgi?req=doc\&base=CMB\&n=18429\#06844743876414539 (дата обращения: 18.04.2020).

7. Бычков, А.И. Актуальные проблемы судебного разбирательства: учеб.пособие / А.И.Бычков.- М.: Инфотропик Медиа,2016. - 480с.

8. Арбитражный процесс [Электронный ресурс]: учебник /под ред. С. В.Никитина. М.: РГУП, 2017- Режим доступа: http://www.consultant.ru/document/Cons_doc_LAW_9878/ (дата обращения: 24.04.2020).

9. «Арбитражный процессуальный кодекс Российской Федерации» от 24.07.2002 № 95-Ф3 (ред. от 25.12.2018) (с изм. и доп., вступ. в силу с 25.12.2018)// Консультант Плюс. [Электронный ресурс]. URL: http://www. consultant.ru/document/Cons_doc_LAW_37800/ (дата обращения: 24.04.2020).

10. Скуратовский, М.Л. О возможной регламентации арбитражного процесса / М. Л. Скуратовский // Арбитражный и гражданский процесс.-2018.-№ 12.-С. 29-32. 
11. Статистические данные Судебного департамента при Верховном Суде РФ о деятельности арбитражных судов за 2018 год [Электронный ресурс]. URL: http://www.cdep.ru/userimages/sudebnaya_statistika/2019/ AC1-svod-2018.xls.

12. Медведев С.В. Меры по обеспечения иска и принцип равенства сторон в споре в гражданском и арбитражном процессе некоторые аспекты / С. В. Медведев // Вестник экономического правосудия Российской Федерации. - 2018. - № 11.- С. 99-113

13. Арбитражный процесс [Электронный ресурс]: учебник /под ред. В.В.Яркова. М.: Статут,2 017 http://www. consultant.ru/edu/student/download_books/book/arbitrazhnyj_process_uchebnik_av_bsalyamov_db_abushenko_ kl_branovickij_i_dr_otv_red_vv_yarkov/ (дата обращения: 10.04.2020)

14. Андреев, А.А.Злоупотребление правом в цивилистическомпроцессе /А.А.Андреев// Современный юрист.2017. - № 1.- С. 51-55.

15. Васьковский Е. В. Процессуальные средства защиты интересов ответчика в арбитражном процессе / Е. В. Васьковский // Издательство «Проспект». - 2016. - № 7.- С.67-75

16. Корсунова А.С. Злоупотребление процессуальными правами в арбитражном процессе: некоторые теоретические и практические аспекты \\ Проблемы экономики и юридической практики -2018. - № 1-С.152-155 